\title{
PERMAINAN TRADISIONAL DHAKONAN MENCEGAH PROGRESIFITAS TINGKAT DEMENSIA PADA LANSIA
}

Mita Nur Lathifah, Program Studi Pendidikan Ners, Universitas Airlangga Surabaya

e-mail; mitanurlathifah@gmail.com

Joni Haryanto, Program Studi Pendidikan Ners, Universitas Airlangga Surabaya

e-mail; joni.h.unair@gmail.com

Rista Fauziningtyas, Program Studi Pendidikan Ners, Universitas Airlangga Surabaya

e-mail,rfauziningtyas@gmail.com

\section{ABSTRACT}

One of the elderly problem is dementia, which can interfere daily activity. One of the safe treatment for elderly with dementia is reminiscence therapy with dhakonan traditional games. The purpose of this study is explain the effect of dhakonan traditional games on dementia level in the elderly.

The design of this study was quasy-experiment design. The population was elderly with dementia in Desa Wedoro Kecamatan Waru Kabupaten Sidoarjo. The total sample were 20 respondents who appropriate to inclusion criteria. The sampling was simple random sampling. The independent variable was dhakonan traditional games, the dependent variable were cognitive function, depression, and dementia level. Data were collected using quissionaires of Mini Mental State Examination (MMSE), Geriatric Depression Scale (GDS), dan Functional Assessment Staging Tool (FAST). Data analysis were Wilcoxon Sign Rank Test and Mann Whitney Test with significance level of $\alpha<0,05$.

Based on Wilcoxon Sign Rank Test found that $p<0,05$ for cognitive function, depression level, and dementia level in treatment group (cognitive function, $p=0,005$; depression level, $p=0,005$; dementia level, $p=0,014$ ), it means the dhakonan traditional games had an effect to the dementia level in the elderly.

The conclusions of this study was the dhakonan traditional games significantly increased cognitive function, decreased depression level and prevent progressifity of dementia level. The future studies can add the respondents and behavioral changes in elderly with dementia.

Keyword: dhakonan traditional games, elderly, cognitive function, depression, dementia

\section{PENDAHULUAN}

Keberhasilan pembangunan bidang kesehatan di Indonesia dapat dilihat dari peningkatan Umur Harapan Hidup (UHH) yang menyebabkan peningkatan jumlah penduduk lansia dan akan meningkatkan jumlah angka kesakitan karena penyakit akibat proses degeneratif seperti demensia [1]. Demensia merupakan kumpulan gejala neurodegeneratif yang timbul karena kelainan yang bersifat kronis dan progesif disertai dengan gangguan fungsi kognitif seperti kemampuan mengingat, proses berpikir, kalkulasi, kapasitas belajar, orientasi, bahasa, dan mengambil keputusan [2]. Penurunan fungsi kognitif dan memori tidak hanya mempengaruhi aktivitas sehari-hari, tetapi juga akan menyebabkan perubahan tingkah laku dan kontrol emosi [3].

Lansia demensia di dunia mencapai lebih dari 46,8 juta jiwa, sedangkan penduduk lansia di Asia yang mengalami demensia sejumlah 22 juta jiwa. Indonesia termasuk dalam sepuluh besar negara di dunia yang memiliki tingkat penderita demensia tertinggi yakni sebesar 1,2 juta jiwa [4]. Salah satu provinsi yang mempunyai jumlah lansia terbanyak pada tahun 2015 adalah Jawa Timur yakni 11,5\% atau sekitar 4,2 juta jiwa dan Sidoarjo merupakan salah satu kabupaten yang memiliki lansia terbanyak sejumlah 131.517 jiwa [5]. Data Dinas Kesehatan Kabupaten Sidoarjo tahun 2015 menunjukkan bahwa Kecamatan Waru memiliki jumlah lansia terbanyak yakni 8.453 jiwa. Proporsi lansia demensia di Indonesia sebesar $15 \%$ dari jumlah penduduk lansia [6].

Data awal survey di Puskesmas Waru terdapat 14 wilayah kerja. Desa Wedoro merupakan desa dengan jumlah lansia tertinggi yakni 517 orang. Hasil wawancara dengan 25 lansia, peneliti menemukan 18 lansia mengalami gangguan kognitif. Peneliti melakukan survey menggunakan clock drawing test dan didapatkan 1 orang mendapatkan skor 0 atau gangguan kognitif berat, 2 orang mendapatkan skor 1 atau gangguan kognitif berat, 10 orang mendapat skor 2 atau 
gangguan kognitif sedang, dan 5 orang mendapat skor 3 atau gangguan kognitif ringan.

Masalah yang dihadapi lansia dengan demensia antara lain perubahan fungsi kognitif, tingkah laku, penurunan aktivitas fisik, mental, fungsi sosial dan penurunan kualitas hidup [7]. Penurunan fungsi kognitif pada demensia menyebabkan lansia mudah lupa bahkan tidak mampu mempertahankan informasi yang baru diterima. Gangguan kognitif dan ketergantungan lansia dalam memenuhi kebutuhan sehari-hari dapat menyebabkan kemungkinan terjadi elder abuse yang akan berdampak pada penurunan kesehatan lansia [8].

Salah satu terapi non farmakologis untuk mengatasi demensia adalah terapi kenangan. Terapi kenangan akan membantu lansia mengenang masa lalu yang menyenangkan sejak masa anak hingga dewasa serta hubungan dengan keluarga dan orang lain kemudian me-recall item memori yang pernah ada [9]. Terapi kenangan juga dapat meningkatkan fungsi kognitif dan mood pada seseorang dengan demensia [10]. Terapi kenangan dapat dilakukan dengan metode permainan karena hal itu mengingatkan lansia pada memori masa kecil yang menyenangkan. Bermain memiliki peran yang penting dalam perkembangan kognitif dan emosi [11]. Permainan yang dapat dilakukan salah satunya adalah dhakonan yang dapat melatih otak untuk membuat strategi, meningkatkan kecerdasan, melatih konsentrasi, mengambil keputusan, kemampuan berhitung dan menganalisa sehingga akan meningkatkan fungsi kognitif seseorang [12] [13]. Oleh karena itu, peneliti ingin meneliti tentang pengaruh permainan tradisional dhakonan terhadap tingkat demensia pada lansia.

\section{BAHAN DAN METODE}

Desain penelitian yang digunakan adalah Quasy-Eksperimental. Populasi target penelitian ini adalah lansia dengan demensia di Kabupaten Sidoarjo sejumlah 19.727 jiwa dari 18 kecamatan. Kecamatan Waru merupakan kecamatan yang memiliki jumlah lansia terbanyak yaitu 8.453 jiwa dari 14 desa. Salah satu desa yang mempunyai jumlah lansia tertinggi adalah Desa Wedoro sebanyak 517 jiwa. Desa wedoro memiliki 7 dusun. Dusun yang menjadi lokasi penelitian adalah Dusun Wedoro Utara dan Dusun Wedoro Belahan.

Populasi terjangkau penelitian ini adalah lansia demensia di Desa Wedoro yang telah memenuhi kriteria inklusi dan eksklusi yang ditetapkan peneliti. Kriteria inklusi pada penelitian ini adalah : lansia berusia 60-74 tahun, hidup dengan keluarga, masa muda pernah bermain dhakonan, memiliki nilai kognitif $\leq 4$ saat diukur dengan Clock Drawing Test (CDT), bersedia menjadi responden penelitian dan mengikuti kegiatan secara penuh. Kriteria eksklusi penelitian ini antara lain : lansia yang memiliki gangguan penglihatan dan pendengaran yang berat, memiliki riwayat penyakit stroke, parkinson, diabetes mellitus, tumor otak, trauma kepala, dan riwayat gangguan jiwa.

Penentuan sampel penelitian menggunakan teknik probability sampling dengan pendekatan simple random sampling. Peneliti mengocok nama posyandu dan memilih 2 posyandu di Desa Wedoro. Responden yang menjadi kelompok kontrol adalah lansia di posyandu Dusun Wedoro Belahan, sedangkan kelompok perlakuan adalah lansia di posyandu Dusun Wedoro Utara. Besar sampel dalam penelitian ini adalah 20 orang, masing-masing kelompok memiliki 10 orang responden.

Variabel independen yang digunakan dalam penelitian ini adalah permainan tradisional dhakonan. Variabel dependen penelitian adalah fungsi kognitif, tingkat depresi, dan tingkat demensia.

Instrumen untuk mengukur variabel dependen tingkat kognitif adalah Mini Mental State Examination (MMSE) yang memiliki 15 soal dalam 6 domain, variabel tingkat depresi diukur dengan Geriatric Depression Scale (GDS) dengan 30 soal, dan variabel tingkat demensia diukur menggunakan Functional Assessment Staging Tools (FAST) yang memiliki 7 stadium demensia berdasarkan karakteristik dan nilai fungsi kognitif. Variabel independen permainan tradisional dhakonan diukur menggunakan Satuan Acara Kegiatan (SAK).

Lokasi penelitian adalah di Dusun Wedoro Belahan dan Dusun Wedoro Utara, Desa Wedoro, Kecamatan Waru, Kabupaten Sidoarjo. Penelitian dilaksanakan selama 3 minggu mulai 14 Juni- 4 Juli 2016. Peneliti melakukan pretest dengan kuisioner MMSE dan GDS pada responden satu hari sebelum intervensi permainan dhakonan, kemudian peneliti menggunakan instrumen FAST untuk menentukan tingkat demensia. Permainan tradisional dhakonan dilakukan pada kelompok perlakuan sebanyak 9 kali selama 3 minggu, dengan frekuensi 3 kali seminggu dan setiap pertemuan responden bermain 3 babak dan melakukan secara berpasangan. Saat lansia melakukan permainan, peneliti mengobservasi 
respon lansia dan dituliskan di dalam log book. Post test dilakukan pada kedua kelompok setelah intervensi hari terakhir dan dengan menggunakan kuisioner MMSE dan GDS, kemudian peneliti menentukan tingkat demensia dengan FAST.

Data penelitian yang didapatkan diolah dengan membuat penilaian pada kuisioner MMSE, GDS, dan FAST. Tahap selanjutnya peneliti melakukan coding, tabulasi data, dan menganalisis dengan uji statistik Wilcoxon Sign Rank Test dan Mann Whitney Test.

\section{HASIL PENELITIAN}

Peneliti melakukan uji normalitas sebelum melakukan analisis data. Hasil uji normalitas didapatkan nilai $\mathrm{p}>0,05$ yang berarti data termasuk data normal. Tahap selanjutnya peneliti melakukan uji homogenitas pada kelompok kontrol dan perlakuan. Tabel 1 menunjukkan bahwa nilai $p>0,05$ pada setiap karakteristik yang berarti kedua kelompok memiliki distribusi frekuensi karakteristik yang sama.

Data tabel 2 menunjukkan bahwa hasil uji wilcoxon sign rank test pada fungsi kognitif nilai p kelompok kontrol sebelum dan sesudah intervensi adalah $p=0,183$ sehingga $p>0,05$ yang berarti tidak ada perbedaan antara hasil pre test dan post test.

Tabel 1. Karakteristik responden di Desa Wedoro Kecamatan Waru Kabupaten Sidoarjo

\begin{tabular}{|c|c|c|c|c|c|c|c|}
\hline \multirow{2}{*}{ No } & \multirow{2}{*}{ Karakteristik } & \multicolumn{2}{|c|}{ Kontrol } & \multicolumn{2}{|c|}{ Perlakuan } & \multicolumn{2}{|c|}{ Jumlah } \\
\hline & & $f(x)$ & $(\%)$ & $f(x)$ & $(\%)$ & $f(x)$ & $(\%)$ \\
\hline \multirow[t]{5}{*}{1} & Usia & & & & & & \\
\hline & a. $60-74$ th & 10 & 100 & 10 & 100 & 20 & 100 \\
\hline & b. $75-90$ th & 0 & 0 & 0 & 0 & 0 & 0 \\
\hline & c. $>90$ th & 0 & 0 & 0 & 0 & 0 & 0 \\
\hline & Mann Whitney Test & \multicolumn{6}{|c|}{$p=0,721$} \\
\hline \multirow[t]{3}{*}{2} & Jenis kelamin & & & & & & \\
\hline & a. Perempuan & 10 & 100 & 10 & 100 & 20 & 100 \\
\hline & b. Laki-laki & 0 & 0 & 0 & 0 & 0 & 0 \\
\hline & Mann Whitney Test & \multicolumn{6}{|c|}{$p=1,00$} \\
\hline \multirow[t]{8}{*}{3} & Pendidikan & & & & & & \\
\hline & a. Tidak lulus SD & 3 & 30 & 4 & 40 & 7 & 35 \\
\hline & b. SD & 4 & 40 & 1 & 10 & 5 & 25 \\
\hline & c. Tidak lulus SMP & 0 & 0 & 1 & 10 & 1 & 5 \\
\hline & d. SMP & 2 & 20 & 3 & 30 & 5 & 25 \\
\hline & e. SMA & 1 & 10 & 1 & 10 & 2 & 10 \\
\hline & f. Perguruan Tinggi & \multirow{2}{*}{\multicolumn{6}{|c|}{$\mathrm{p}=0,906$}} \\
\hline & Mann Whitney Test & & & & & & \\
\hline \multirow[t]{6}{*}{4} & Pekerjaan terdahulu & & & & & & \\
\hline & a. Buruh/karyawan & 5 & 50 & 4 & 40 & 9 & 45 \\
\hline & b. Wiraswasta & 1 & 10 & 3 & 30 & 4 & 20 \\
\hline & c. PNS & 0 & 0 & 0 & 0 & 0 & 0 \\
\hline & d. Tidak Bekerja & 4 & 40 & 3 & 30 & 7 & 35 \\
\hline & Mann Whitney Test & \multicolumn{6}{|c|}{$p=0,967$} \\
\hline \multirow[t]{6}{*}{5} & Pekerjaan sekarang & & & & & & \\
\hline & a. Buruh/karyawan & 2 & 20 & 0 & 0 & 2 & 10 \\
\hline & b. Wiraswasta & 2 & 20 & 4 & 40 & 6 & 30 \\
\hline & c. PNS & 0 & 0 & 0 & 0 & 0 & 0 \\
\hline & d. Tidak Bekerja & 6 & 60 & 6 & 60 & 12 & 60 \\
\hline & Mann Whitney Test & \multicolumn{6}{|c|}{$\mathrm{p}=0,728$} \\
\hline \multirow[t]{4}{*}{6} & Kebiasaaan konsumsi kopi & & & & & & \\
\hline & a. $\mathrm{Ya}$ & 6 & 60 & 5 & 50 & 11 & 55 \\
\hline & b. Tidak & 4 & 40 & 5 & 50 & 9 & 45 \\
\hline & Mann Whitney Test & \multicolumn{6}{|c|}{$\mathrm{p}=0,661$} \\
\hline \multirow[t]{4}{*}{7} & $\begin{array}{l}\text { Kebiasaan menggunakan pasta gigi } \\
\text { mengandung flouride }\end{array}$ & & & & & & \\
\hline & a. Ya & 10 & 100 & 10 & 100 & 20 & 100 \\
\hline & b. Tidak & 0 & 0 & 0 & 0 & 0 & 0 \\
\hline & Mann Whitney Test & \multicolumn{6}{|c|}{$p=1,00$} \\
\hline
\end{tabular}


Tabel 2. Hasil fungsi kognitif pre test dan post test pada kelompok kontrol dan perlakuan.

\begin{tabular}{lcccccccc}
\hline \multirow{2}{*}{ Fungsi Kognitif } & \multicolumn{3}{c}{ Kelompok Kontrol } & \multicolumn{3}{c}{ Kelompok Perlakuan } \\
\cline { 2 - 10 } & \multicolumn{3}{c}{ Pre } & \multicolumn{3}{c}{ Post } & \multicolumn{3}{c}{ Pre } & \multicolumn{3}{c}{ Post } \\
\cline { 2 - 10 } & $\mathrm{f}(\mathrm{x})$ & $\%$ & $\mathrm{f}(\mathrm{x})$ & $\%$ & $\mathrm{f}(\mathrm{x})$ & $\%$ & $\mathrm{f}(\mathrm{x})$ & $\%$ \\
\hline Normal & 0 & 0 & 0 & 0 & 0 & 0 & 3 & 30 \\
Gangguan Kognitif Ringan & 7 & 70 & 4 & 40 & 5 & 50 & 7 & 70 \\
Gangguan Kognitif Sedang & 3 & 30 & 6 & 60 & 5 & 50 & 0 & 0 \\
Gangguan Kognitif Berat & 0 & 0 & 0 & 0 & 0 & 0 & 0 & 0 \\
Jumlah & 10 & 100 & 10 & 100 & 10 & 100 & 10 & 100 \\
Uji Wilcoxon Signed & \multicolumn{4}{c}{$\mathrm{p}=0,183$} & & & $\mathrm{p}=0,005$ & \\
Rank Test & \multicolumn{3}{c}{$\alpha=0,05$} & & & \\
\hline
\end{tabular}

Uji Mann Whitney Test pre intervensi $p=0,704 \quad \alpha=0,05$

Uji Mann Whitney Test post intervensi $p=0,002 \quad \alpha=0,05$

Tabel 3. Hasil tingkat depresi pre test dan post test pada kelompok kontrol dan perlakuan.

\begin{tabular}{lcccccccc}
\hline \multirow{2}{*}{ Tingkat Depresi } & \multicolumn{3}{c}{ Kelompok Kontrol } & \multicolumn{3}{c}{ Kelompok Perlakuan } \\
\cline { 2 - 9 } & \multicolumn{3}{c}{ Pre } & \multicolumn{3}{c}{ Post } & \multicolumn{3}{c}{ Pre } & \multicolumn{2}{c}{ Post } \\
\cline { 2 - 9 } & $\mathrm{f}(\mathrm{x})$ & $\%$ & $\mathrm{f}(\mathrm{x})$ & $\%$ & $\mathrm{f}(\mathrm{x})$ & $\%$ & $\mathrm{f}(\mathrm{x})$ & $\%$ \\
\hline Normal & 5 & 50 & 7 & 70 & 6 & 60 & 10 & 100 \\
Depresi Ringan & 5 & 50 & 2 & 20 & 4 & 40 & 0 & 0 \\
Depresi Berat & 0 & 0 & 10 & 10 & 0 & 0 & 0 & 0 \\
Jumlah & 10 & 100 & 10 & 100 & 10 & 100 & 10 & 100 \\
Uji Wilcoxon Signed & \multicolumn{4}{c}{$\mathrm{p}=0,100$} & & & $\mathrm{p}=0,005$ & \\
Rank Test & \multicolumn{4}{c}{$\alpha=0,05$} & & & $\alpha=0,05$ \\
\hline
\end{tabular}

Uji Mann Whitney Test pre intervensi $p=0,647 \quad \alpha=0,05$

Uji Mann Whitney Test post intervensi $p=0,040 \quad \alpha=0,05$

Tabel 4. Hasil tingkat demensia pre test dan post test pada kelompok kontrol dan perlakuan.

\begin{tabular}{|c|c|c|c|c|c|c|c|c|}
\hline \multirow{3}{*}{ Tingkat Demensia } & \multicolumn{4}{|c|}{ Kelompok Kontrol } & \multicolumn{4}{|c|}{ Kelompok Perlakuan } \\
\hline & \multicolumn{2}{|c|}{ Pre } & \multicolumn{2}{|c|}{ Post } & \multicolumn{2}{|c|}{ Pre } & \multicolumn{2}{|c|}{ Post } \\
\hline & $f(x)$ & $\%$ & $f(x)$ & $\%$ & $f(x)$ & $\%$ & $f(x)$ & $\%$ \\
\hline Stadium 1 (normal) & 0 & 0 & 0 & 0 & 0 & 0 & 0 & 0 \\
\hline Stadium 2 (Gangguan kognitif subjektif) & 0 & 0 & 0 & 0 & 0 & 0 & 1 & 10 \\
\hline $\begin{array}{l}\text { Stadium } 3 \text { (Gangguan kognitif } \\
\text { ringan/awal demensia) }\end{array}$ & 7 & 70 & 4 & 40 & 5 & 50 & 9 & 90 \\
\hline Stadium 4 (demensia ringan) & 2 & 20 & 4 & 40 & 5 & 50 & 0 & 0 \\
\hline Stadium 5 (demensia sedang) & 1 & 10 & 2 & 20 & 0 & 0 & 0 & 0 \\
\hline Stadium 6 (demensia berat) & 0 & 0 & 0 & 0 & 0 & 0 & 0 & 0 \\
\hline Stadium 7 (demensia berat) & 0 & 0 & 0 & 0 & 0 & 0 & 0 & 0 \\
\hline Jumlah & 10 & 100 & 10 & 100 & 10 & 100 & 10 & 100 \\
\hline Uji Wilcoxon Signed Rank Test & \multicolumn{4}{|c|}{$\begin{array}{c}p=0,157 \\
\alpha=0,05\end{array}$} & \multicolumn{4}{|c|}{$\begin{array}{c}p=0,014 \\
\alpha=0,05\end{array}$} \\
\hline
\end{tabular}

Uji Mann Whitney Test pre intervensi $p=0,579 \quad \alpha=0,05$

Uji Mann Whitney Test post intervensi $p=0,004 \quad \alpha=0,05$

Tabel 3 menunjukkan hasil uji Wilcoxon Signed Rank Test pada tingkat depresi kelompok kontrol $\mathrm{p}=0,100$ yang artinya tidak ada perbedaan antara hasil pre test dan post test. Pada kelompok perlakuan didapatkan $p=0,005$ yang berarti terdapat perbedaan yang signifikan antara hasil pre test dan post test. Pada pre test kelompok kontrol dan perlakuan hasil uji Mann Whitney Test diperoleh $\mathrm{p}=0,647$ yang artinya tidak ada perbedaan yang signifikan antara kedua kelompok, sedangkan pada post test didapatkan hasil $p=0,040$ yang berarti ada perbedaan yang cukup signifikan antara kelompok kontrol dan kelompok perlakuan. Hal ini dapat disimpulkan bahwa terdapat pengaruh permainan tradisional dhakonan terhadap tingkat depresi lansia.

Berdasarkan tabel 3, hasil uji Wilcoxon Signed Rank Test pada tingkat demensia kelompok kontrol menunjukkan $p=0,157$ yang artinya tidak ada perbedaan antara hasil pre test dan post test. Pada kelompok perlakuan didapatkan $\mathrm{p}=0,014$ yang berarti terdapat perbedaan antara hasil pre test dan post test. Pada pre test kelompok kontrol dan perlakuan hasil uji Mann Whitney Test diperoleh $\mathrm{p}=0,579$ 
yang artinya tidak ada perbedaan yang antara kedua kelompok, sedangkan pada post test didapatkan hasil $p=0,004$ yang berarti ada perbedaan yang signifikan antara kelompok kontrol dan kelompok perlakuan. Hal ini dapat disimpulkan bahwa terdapat pengaruh permainan tradisional dhakonan terhadap tingkat demensia lansia.

\section{PEMBAHASAN}

Pada kelompok perlakuan terdapat perbedaan yang signifikan terhadap fungsi kognitif sebelum dan sesudah pemberian permainan tradisional dhakonan. Sebelum intervensi permainan dhakonan, fungsi kognitif responden tergolong dalam gangguan kognitif ringan dan gangguan kognitif sedang, setelah intervensi dilakukan fungsi kognitif responden meningkat menjadi normal dan gangguan kognitif ringan. Pada data tingkat depresi kelompok perlakuan juga ditemukan perbedaan yang cukup signifikan antara hasil sebelum dan sesudah intervensi.

Sebelum diberikan intervensi tingkat depresi pada kelompok perlakuan adalah depresi ringan dan tidak ada depresi atau normal. Pada saat responden telah melakukan permainan dhakonan, semua responden mengalami penurunan tingkat depresi menjadi normal atau tidak ada depresi.

Data tingkat demensia sebelum intervensi permainan dhakonan didapatkan responden mengalami demensia stadium 3 atau early dementia dan stadium 4 atau demensia ringan dengan prosentase yang sama. Hasil uji statistik menunjukkan bahwa perbedaan tingkat demensia sebelum dan sesudah intervensi pada kelompok perlakuan terdapat perbedaan yang signifikan. Pada sebagian besar responden setelah diberikan intervensi tingkat demensia menjadi stadium 3 dan dan terdapat 1 responden yang mengalami demensia stadium 2 atau Subjektif Cognitive Impairment. Hasil penelitian ini menunjukkan bahwa setelah melakukan permainan dhakonan fungsi kognitif lansia menjadi meningkat sehingga tidak terjadi kenaikan tingkat demensia ke tingkat yang lebih berat, dengan kata lain permainan dhakonan dapat mencegah progresifitas demensia.

Penelitian membuktikan bahwa beberapa penelitian sebelumnya mengenai terapi reminiscence efektif untuk meningkatkan kognitif dan menurunkan depresi pada lansia demensia [7]. Terapi reminiscence dapat meningkatkan kemampuan kognitif, mood dan perbaikan perilaku pada penderita demensia [10]. Penelitian lain mengatakan bahwa
Productive Activities with reminiscence in Occupational Therapy (PAROT) dapat meningkatkan fungsi kognitif dan menurunkan tingkat depresi lansia. Penelitian ini menggunakan instrumen CSSD (Cornell Scale for Depression in Dementia) dan MOSES (Multidimensional Observation Scale for Elderly Subjects) [14].

Terapi kenangan bertujuan untuk memberi kesempatan bersosialisasi, pengalihan, kesenangan, komunikasi, mengurangi depresi dan isolasi sosial serta meningkatkan harga diri dan kepuasan hidup lansia berdasarkan penilaian diri sendiri dan prestasi yang telah dicapai [15]. Terapi kenangan berpengaruh pada aspek kognitif, psikologis, kebiasaan sosial dan tingkat kesehatan lansia [16]. Terapi kenangan akan memberikan efek bahagia pada seseorang, menurunkan tingkat depresi serta meningkatkan kemampuan kognitif [14]. Tidak hanya itu, terapi kenangan juga akan meningkatkan harga diri dan kepuasan hidup lansia, meningkatkan kemampuan untuk beradaptasi terhadap stres melalui kemampuan dalam penyelesaian masalah dan peningkatan pada hubungan sosial dengan orang lain [15]. Terapi ini akan memaksimalkan potensi yang dimiliki dan memberikan nilai positif pada lansia.

Terapi kenangan akan memberikan impuls pada memori. Memori merupakan suatu proses impuls sensorik yang akan dipakai pada masa yang akan datang sebagai pengatur aktivitas motorik dan proses berpikir. Penyimpanan memori sebagian besar terjadi di korteks serebri yang memiliki lebih dari 10 milyar sel otak dan berhubungan dengan sel-sel lain. Satu sel otak memiliki hubungan dengan 4.00010.000 sel otak lain melalui zat penghantar rangsang atau neurotransmitter yaitu zat kimia maupun impuls listrik dalam tubuh [17].

Penyimpanan informasi juga merupakan peran dari sinaps, sehingga setiap sinyal sensorik yang melewati jalur sinaps di masa datang akan mampu menyalurkan sinyal yang sama, proses penyampaian sinyal disebut fasilitasi. Jika sinaps sering dilalui oleh sinyal sensorik maka akan terfasilitasi dan sinyal yang timbul dari otak sudah dapat menyalurkan impuls melalui jalur sinaps yang sama meskipun belum ada impuls sensorik. Kegiatan fasilitas sinaps seperti ini akan mempengaruhi proses berpikir bawah sadar (sub conscious mind) sehingga menimbulkan persepsi dari pengalaman sensasi yang sebenarnya dan tubuh dapat berespon walaupun efek yang ditimbulkan hanya suatu memori dari sensasi. 
Jika memori sudah disimpan dalam sistem saraf, maka memori tersebut akan menjadi bagian dari mekanisme pengolahan dan masuk ke sistem ingatan manusia. Salah satu bagian otak yang berperan dalam menyimpan memori adalah hippoccampus. Hippoccampus dapat memindahkan informasi dari ingatan jangka pendek menjadi ingatan jangka panjang yang merupakan tempat penyimpanan informasi yang relatif permanen [18] [19].

Permainan dhakonan akan membangkitkan kenangan masa lalu lansia yang menyenangkan dan dapat merangsang otak untuk berpikir, melatih konsentrasi, membuat strategi, dan menganalisa. Rangsangan pada permainan dhakonan direspon oleh penglihatan (visual) dan gerakan (kinestetik). Pada visual, cahaya yang dilihat oleh mata diteruskan oleh lensa dan diterima retina, kemudian sinyal tersebut melalui saraf optik menuju kiasma optikum (optic chiasm) kemudian melalui traktus optikus hingga masuk ke otak. Pada kinestetik fungsi aferen neuron sensorik menghantarkan informasi dari reseptor menuju ke corda spinalis kemudian melalui parabrachial complex (PBC) dan periaquaductal grey (PAG) hingga ke otak. Kedua respon tersebut akan menuju korteks otak lalu ke sistem limbik yang didalamnya terdapat amigdala yang berperan untuk mengatur emosi dan memori, serta terdapat hippocampus yang berperan dalam penyimpanan memori. Saat bermain dhakonan, pada hippocampus dan amigdala terjadi proses retrieval memory episodik untuk menggali memori yang telah disimpan dalam otak. Pada tahap selanjutnya impuls diteruskan ke prefrontal dan dipengaruhi oleh spiritual node yang akan menimbulkan perasaan senang dan nyaman bila ingatan yang terdapat pada hippocampus dan amigdala tersebut positif. Impuls yang masuk ke dalam prefrontal akan merangsang prefrontal untuk bekerja sesuai fungsinya seperti perencanaan, pengorganisasian, dan pemecahan masalah. Rasa bahagia yang muncul akan memacu prefrontal untuk mengambil keputusan (judgement) dengan lancar dan memecahkan masalah secara bertahap, selain itu terdapat respon prefrontal untuk berpikir akan mempengaruhi peningkatan kognitif dan penurunan depresi.

Pada penelitian ini permainan dhakonan sebagai reminiscence therapy karena akan mengingatkan lansia pada masa lalu, memberikan efek bahagia serta dapat meningkatkan kognitif serta penurunan depresi pada lansia. Permainan dhakonan dilakukan 9 kali selama 3 minggu dengan tujuan melatih fungsi kognitif dan menurunkan depresi. Pada post test kelompok perlakuan didapatkan peningkatan fungsi kognitif, penurunan tingkat depresi dan tidak terjadi peningkatan tingkat demensia. Pada fungsi kognitif diperoleh peningkatan pada sebagian besar aspek fungsi kognitif yang terdiri dari memori, bahasa, fungsi eksekutif, dan visuospasial. Pada tingkat depresi diperoleh penurunan kecemasan, agitasi, perasaan depresi serta peningkatan semangat. Tingkat demensia saat post test tidak ditemukan progresifitas ke tingkat yang lebih berat. Permainan dhakonan dapat meningkatkan mood, selain itu dilihat dari aspek sosial permainan ini membuat lansia menjalin interaksi dengan sesama lansia sehingga dapat menimbulkan rasa nyaman. Jika stimulasi permainan dhakonan dilakukan secara berulang akan memberikan pengaruh pada otak yang akan dengan sendirinya menghantarkan impuls melalui sinaps yang sama sehingga memori dapat mudah diingat dan akan mencegah perkembangan tingkat demensia serta menurunkan tingkat depresi.

Berdasarkan teori Miller yakni The Functional Consequences Theory, lansia akan mengalami perubahan terkait usia dan memiliki faktor risiko yang membuat kesehatan lansia menurun (negative functional consequences). Perawat harus memberikan intervensi dengan baik sehingga akan menimbulkan konsekuensi fungsional positif (positive functional consequences) atau wellness outcome seperti peningkatan kebijaksanaan, kreativitas, dan akal sehat, peningkatan kesejahteraan, serta lansia dapat melaksanakan fungsinya lebih baik dalam kehidupan sehari-hari [20]. Intervensi (nursing intervention) yang dapat dilakukan adalah pengajaran mengenai kognitif dan penuaan, teknik peningkatan memori, serta kegiatan untuk mempromosikan kegiatan untuk kebugaran otak seperti melakukan permainan tradisional dhakonan. Pada lansia yang telah diberikan intervensi permainan dhakonan diperoleh peningkatan kesehatan dan kualitas hidup lansia meliputi peningkatan fungsi kognitif, penurunan tingkat depresi hingga tidak terjadi peningkatan tingkat demensia ke tahap yang lebih berat.

\section{KESIMPULAN}

1. Demensia dipengaruhi oleh usia, tingkat pendidikan, pekerjaan, kebiasaan mengonsumsi kopi dan penggunaan flouride. 
2. Pemberian intervensi permainan tradisional dhakonan dapat meningkatkan fungsi kognitif lansia melalui latihan menganalisa, pemikiran strategi, menghitung, serta melatih motorik halus lansia.

3. Pada permainan tradisional dhakonan dapat terjadi penurunan tingkat depresi hingga menjadi normal dengan melakukan interaksi sosial bersama pasangan bermain dan dapat mengingat kembali masa lalu yang menyenangkan.

4. Efek dari permainan tradisional dhakonan dapat mempertahankan tingkat demensia atau mencegah progresifitas demensia karena efektif untuk meningkatkan fungsi kognitif dan menurunkan tingkat depresi.

\section{SARAN}

Kegiatan permainan tradisional dhakonan dapat dimasukkan ke dalam program rutin posyandu lansia karena dapat meningkatkan fungsi kognitif, menurunkan depresi, mencegah progresifitas tingkat demensia serta meningkatkan kualitas hidup lansia. Diharapkan perawat dapat menghimbau lansia untuk tetap aktif melakukan permainan tradisional dhakonan dengan melibatkan keluarga. Peneliti selanjutnya dapat memperbanyak jumlah sampel dan menambahkan variabel perubahan perilaku pada lansia demensia.

\section{KEPUSTAKAAN}

[1] KEMENKES RI. Buletin Jendela Data dan Informasi Kesehatan. Jakarta: KEMENKES $\mathrm{RI} ; 2013$.

[2] WHO. About Us: World Health Organization; 2016, diakses 8 April 2016,http://www.who.int/topics/dementia/en I

[3] Nugroho. Keperawatan Gerontik dan Geriatri. Jakarta: EGC; 2008.

[4] Prince, Martin, Wimo, Guerchet, Ali, Wu, \& Prina. World Alzheimer Report 2015: The Global Impact of Dementia. London: Alzheimer's Disease International; 2015.

[5] Badan Pusat Statistik. Kebutuhan dan Ketenagakerjaan untuk Pembangunan Berkelanjutan. Jakarta: BPS; 2015.

[6] Sri Hartati \& Widayanti 'Clock Drawing: Asesmen untuk Demensia', Jurnal Psikologi Undip, 2010,vol. 7, no. 1.

[7] Huang, HC, Chen, Hu, Liu, Kuo, \& Chiu. Reminiscence Therapy Improves Cognitive Functions and Reduces Depressive Symptoms in Elderly People With
Dementia: A Meta-Analysis of Randomized Controlled Trials. Journal of the American Medical Directors Association. 2015; 12: 1087-1094.

[8] Stuart G.W. Principles and practice of psychiatric Nursing. 9th ed. Missouri: Mosby; 2009.

[9] Syarniah. Pengaruh Terapi Kelompok Reminiscence Terhadap Depresi pada Lansia di Panti Sosial Tresna Werdha Budi Sejahtera Provinsi Kalimantan Selatan. Tesis. Depok: Universitas Indonesia; 2010.

[10] Cotelli M. Reminiscence Therapy in Dementia: A Review. Maturitas. 2012;203205.

[11] Tadkiroatun Musfiroh. Bermain untuk Pengembangan Aspek Bahasa dan Motorik. Skripsi. Yogyakarta: Universitas Negeri Yogyakarta; 2008.

[12] Donkers, Uiterwijk, \& Voogt. Mancala Games - topics in Artificial Intellegence and Mathematics. Step by Step. Proceeding of the 4th Colloquium. Board Games in Academia. Switserland: Universitaries Fribourg; 2002.

[13] Rismawati. Menstimulasi Perkembangan Otak dengan Permainan (untuk Anak Usia 0-12 tahun). Yogyakarta: Pedajogja; 2012.

[14] Nakamae T. Effects of Productive Activities with Reminicence in Occupational Therapy for People with Dementia: A Pilot Randomized Controlled Study. Hong Kong Journal of Occupational Theraphy. 2014;17.

[15] Endang Banon. Pengaruh Terapi Reminiscence dan Psikoedukasi Keluarga Terhadap Kondisi Depresi dan Kualitas Hidup Lansia di Katulampa Bogor. Tesis. Depok: Universitas Indonesia; 2011.

[16] Hsieh \& Wang. Effect of Reminiscene Therapy on Depression in Older Adult.Intenational journal of nursing Studies. 2003:40;335-345.

[17] Latif V Cara Memori Bekerja: 2000 diakses 17 Mei 2016, <http://google.co.id/seacrh?hl=1d\&q=fisiolo gi+memori\&meta>.

[18] B B Lahey. Psychology An Introduction. Ninth Edition. New York: McGraw-Hill; 2007.

[19] J W Santrock. Perkembangan Masa Hidup. Jakarta: Erlangga; 2005.

[20] Carol A Miller. Wellness in Older Adult, 5th ed. Philadelphia: Wolters Kluwer Health; 2012. 